\title{
The different faces of inclusion and exclusion
}

\author{
Aldo Mascareño and Fabiola Carvajal
}

ABSTRACT

The notions of inclusion and exclusion have a long tradition in sociology, but have gained significant currency more recently in public policy analysis. However, a certain conceptual inflexibility arises when the distinction is applied to complex social situations. This article examines the main approaches to inclusion/exclusion in the sociological tradition, systems theory and the theory of new inequalities. On this basis, five interrelated situations of inclusion and exclusion are constructed: self-inclusion/self-exclusion, inclusion by risk/ exclusion by danger, compensatory inclusion, inclusion in exclusion and sub-inclusion. They are illustrated with specific examples to refine an analytical approach to problems of inclusion and exclusion, with a view to contributing to sociological analysis and to assessing the consequences of public and private decisions. Chile. aldo.mascareno@uai.cl

Fabiola Carvajal is a research assistant with the School of Government of Adolfo Ibáñez University in Santiago, Chile. fabi.casep@hotmail.com 


\section{I}

\section{Introduction}

The concepts of inclusion and exclusion began to gain popularity in public policy analysis and practice in the 1990s, especially in Europe and in the work of international organizations. Programmes run by the International Labour Organization (ILO), the United Nations, commissions of the European Union and intersectoral bodies such as the Social Exclusion Unit of the Government of Tony Blair in the United Kingdom, built their social agendas around such concepts (MacPherson, 1997; Porter, 2000; Davies, 2005). Even before then, however, they had been used in French social policy (Lenoir, 1974) to refer to social groups warranting attention from government policy. The now widespread use of the inclusion/ exclusion distinction in policy design reflects the fact that it introduces a readily understandable and broadly applicable strategic and political criterion: people fall within or outside specific social criteria, above or below certain limits which express difference.

Useful though this binary formula may be for policymaking, insofar as it provides concrete guidelines for deciding on measures and visualizing outcomes, from a sociological standpoint, drawing a sharp distinction between inclusion and exclusion is more of an artifice constructed for instrumental purposes than an actual observation of social circumstances. In its static form, the distinction transforms processes (for example, participation versus marginalization) into states (inclusion versus exclusion), attaches social categorizations to individuals (excluded versus included), and, by

This article forms part of the research activities of projects Redes 130008, National Fund for Scientific and Technological Development (FONDECYT) 1140344, 1110437, and Núcleo Milenio Modelos de Crisis (NS130017), ICM-Iniciativa Científica Milenio. demarcating boundaries, impedes the conception of paradoxical constellations in which different modalities of inclusion and exclusion are mingled (Goodin, 1996; Davies, 2005; Sánchez, 2012).

This article reviews the inclusion/exclusion distinction, aiming to overcome its limitations, reveal the paradoxes it masks and identify, conceptually, various forms of inclusion/exclusion that may refer to concrete situations. The hypothesis underlying this exercise is that social practices of different natures exist in modern societies, and these inevitably produce paradoxes that are hidden when the inclusion/exclusion distinction is applied in its static form. In order to address these paradoxes, it is first necessary to identify the conditions of inclusion within exclusion, and the conditions of exclusion within inclusion. This exercise should yield diverse constellations of inclusion/exclusion that take us beyond a static understanding of the distinction, which tends to entrench the very inclusion and exclusion conditions that we are trying to overcome.

To support this hypothesis, this Introduction is followed, in section II, with a reconstruction of the inclusion/exclusion distinction in sociological tradition (Simmel, Durkheim, Parsons), with an emphasis on the paradoxes that it reveals and hides. Section III continues with a systemic elaboration of the distinction (Luhmann, Stichweh), before discussing the proposal of the French school (Fitoussi, Rosanvallon) to show the limitations of the static version of the distinction inclusion/exclusion for addressing the emergence of new inequalities (section IV). On this basis, section $V$ proposes an original classification of different constellations of inclusion/exclusion and illustrates them with specific examples. Section VI offers a summary of the main findings together with their conceptual and public policy implications. 


\section{II}

\section{Paradoxes of inclusion/exclusion in sociological tradition: Georg Simmel, Émile Durkheim, Talcott Parsons}

In the history of sociological thought, the distinction inclusion/exclusion has been associated mostly with the functionalist tradition from Durkheim to Luhmann (Rawal, 2008; Braeckman, 2006; Allman, 2012). Nonetheless, it was Georg Simmel who originally noted the paradoxical nature of the inclusion/exclusion relationship. His essays on the stranger and on secrecy illustrate this point. The stranger is neither in nor out, or may be both at the same time. The stranger belongs to the social group, but comes from beyond; he develops charm and significance, but is not the "owner of soil," either in a physical sense or in terms of social reference (Simmel, 1950a, p. 403). This ambiguity moves the group towards openness with the stranger, from confidence to confession, but at the same time the stranger maintains his freedom in practical terms. In other words, the stranger is not included or excluded; or is just as included as excluded.

Secrecy works in a more radical way: included are those who know; the rest are excluded. This binary use of distinction hides paradoxes, however. Secrecy involves a strong sense (expectation) of difference among persons, based on the possession of knowledge as inner property of the group (Simmel, 1950b). Inclusion in the secret develops the group's identity and its boundaries. Yet there are inclusive groups (nations, creeds) for which the secret consists in "including everybody who is not explicitly excluded" (Simmel, 1950b, p. 369). In this case, Simmel gives the distinction a binary application: "The principle of including that which is not explicitly excluded is opposed by the principle of excluding that which is not explicitly included" (Simmel, 1992, p. 447). This masks the real paradoxes. In political matters, for example, inclusion by the State initially excludes members of other States (until they become "nationalized" or acquire some sort of formal citizenship): it excludes them in inclusion. And in religious matters, inclusion through tolerance means acceptance of the other who is nevertheless excluded as an equal. Inclusion and exclusion appear rather as interpenetrated forms.

In Durkheim's work, the conceptualization of inclusion/exclusion must be reconstructed from the author's analysis of solidarity and anomy. Modern society implies an order of simultaneous inclusions and exclusions: inclusion as organic solidarity, exclusion as spheres outside the division of labour (Durkheim, 2001). This raises new issues of integration, which are reflected in types of suicide (Durkheim, 2002). Paradoxically, the egotistic and anomic suicide (lack of integration) encourages the suicidal to follow a social pattern of suicide by which he or she expresses denial of society (a lonely place, a means, a stage, a note). Also paradoxically, the suicidal must recognize him or herself as a member of society in order to reject the social, otherwise he would be a "death person," not a "suicidal." The suicide is thus included in his (last) exclusion. What Durkheim calls altruistic suicide (high integration) is a refusal of society in the name of society. Semantically, society elaborates such acts of self-sacrifice in terms of the martyr, the hero, the saint (Luhmann, 1993), affirming the act as desirable: exclusion is sustained (and viewed positively) as an act of inclusion.

Parsons goes further than Simmel and Durkheim by giving the inclusion/exclusion distinction explicit sociological meaning: "The process by which previously excluded groups attain full citizenship or membership in the societal community will, in this paper, be called inclusion" (Parsons, 1965, p. 1.015). In a more technical manner, Parsons details this definition as follows: "In view of the pluralistic structure of modem societies, it is quite possible for persons or other units which are in some respects 'outsiders' to be included with 'locals' in other respects [...] inclusion is specifically because of the pluralistic structure of modern societies, not an either-or matter, but one of many partial components of membership and of 'acceptance"" (Parsons, 2007, pp. 73 and 74).

Parsons attributes to inclusion the good, the expectable, the normal; while exclusion is the negative side. His empirical point of reference for this elaboration is what he called the "Negro situation in America" (Parsons, 1965). In that context, the concept of inclusion is predominantly used as a synonym for full citizenship. 
Parsons (1965, p. 1.026) understands this as a matter of "acceptance", that is, "the capacity and opportunity for full participation without informal discrimination." Exclusion defeats this goal. However, paradoxically, exclusion is seldom full exclusion: insofar as full citizenship is an ideal, real citizenship implies exclusions when compared with the ideal. For this reason, Parsons speaks of multiple partial components of membership and acceptance, because ultimately inclusion is a cumulative and incremental outcome, which means that there are always exclusions to be overcome (Mascareño, 2012a).

The binary interpretation of the inclusion/exclusion distinction is thus rendered inadequate by the very reflection it invites. There can never be a single state of full inclusion or exclusion, only situations in which the two coexist.

\section{III}

\section{Inclusion and exclusion in systemic sociology: Niklas Luhmann and Rudolf Stichweh}

Contemporary systemic sociology takes a step forward in identifying complex situations of inclusion/exclusion, although it is still inclined to view the distinction in a binary manner, which again leads to the sublimation of certain paradoxes.

Luhmann's analysis of inclusion/exclusion is precise and innovative: "Inclusion (and by analogy, exclusion) refers only to the way that humans are indicated, i.e. made relevant in communication" (Luhmann, 2005, p. 229). The author clarifies that "the societal system provides for persons and assigns them to positions in the framework of which they can act in keeping with expectations" (Luhmann, 2007a, p. 492). In Luhmann's radical definition of the social in terms of communication, individuals as such are excluded from the social. They can participate in society only when they are engaged in communication. This is what Luhmann means by "indicating" and "made relevant": social communication includes them as "people". This can take different forms, depending on the communication system in question - people vote, buy, sell, are subjects of law, and fall in love, for example-. In all these cases there is inclusion. Inclusion is not a single thing, then; it is not a scheme of (up/down) class observation and is not only about welfare: subalterns are also included with reference to the possibility of subverting the order, and to that extent are observed and controlled. Debtors are also afforded an important place in economic communication, especially if they fall into arrears; and law-breakers may be excluded from multiple communications, but must be included at least in the penitentiary system.

What emerges from this system-related inclusion/ exclusion concept is the affirmation that neither inclusion nor exclusion of individuals is ever absolute: no one is fully included or fully excluded. True, one can always be included as a potential audience in a system in which one does not participate formally or professionally: museums, concerts, the arts in general, expect a larger audience at the weekends, but this participation is qualitatively different from that of the curator, the musician or the artist, and if both things are called "inclusion," then the concept is too imprecise to capture the difference in real social operations. The audience cannot "touch": it is included in the art's exclusion of inclusion, and this is very different from being included or excluded as such.

Instead of opening the distinction to encompass these paradoxes, Luhmann (2005 and 2007a) emphasizes the radicalism of the distinction and speaks of the sphere of inclusion and the sphere of exclusion. The first has low integration, insofar as inclusion in one particular sphere does not imply inclusion in others; the second has high integration, because exclusion from one sphere can imply a chain of exclusions. This affirmation is logical when it is assumed that the principle of functional differentiation is almost fully predominant: having money does not necessarily imply having political power or more rights (low integration of inclusion); but lacking a job implies difficulties in gaining inclusion in education, health care, clothing and so on (high integration of exclusion). The problem is that this undervalues the potential that the social principles of stratification and segmentation retain to alter functional inclusions/exclusions.

Much of what is termed "factic power" is attributable to integrations of inclusion as a result of the persistence of stratification (money can buy votes and legal decisions); 
and the lack of formal work can be replaced by informal work (so that exclusion becomes decoupled from taxation and labour law) or by participation in informal networks that afford indirect access to functional outputs through segmentary groups (Mascareño, 2014). Referring to these spheres as "inclusion" and "exclusion" is to set up a binary distinction that is inconsistent with reality. This scheme is taken to an extreme when inclusion and exclusion are attributed to geographical areas: the "formal" sphere where the rule of law prevails and the favela (Luhmann, 2005, pp. 244 and 245).

The paradox is that Luhmann may observe these problems at both an empirical and a theoretical level, stating that the inclusion/exclusion difference never occurs empirically clearly enough for everyone to be unequivocally assigned to one side or the other (Luhmann, 2005 , p. 246). The question, then, is why maintain the binary distinction at all as a scheme of observation. Why not, rather, deconstruct it in the terms required by the variety of forms of inclusion/exclusion present in modern society? ${ }^{1}$

Rudolf Stichweh (2005, pp. 20-41) attempts to do this by identifying various forms of inclusion by functional systems: inclusion through professional/client relations (health, education, law), voice/exit-options in politics, economy, the arts and the media, inclusion in the role of both producer of performances and public (intimate relationships), and indirect inclusion (for example, in science through training in the education system). All these call for determining the types of inclusion of publics. In most systems, the producers of functional outputs are also part of the system's public: legislators also vote and are subject to the law, salespersons also buy. In law, in particular, there is another sort of inclusion of publics: the cooption of the accused, i.e. those who are obliged (expressly against their will) to participate in judicial communication. And in other spheres, publics are brought into secondary roles (voluntary services, science and amateur music, mass sports), i.e. they participate in

1 This was correctly anticipated by Robles (2005), although his proposal over-emphasizes individuation as a reference problem, and thus loses other sociological sources that place tension on inclusion and exclusion relations. a restricted manner (local and non-specialized) in the system communication.

As is plain to see, none of these forms of inclusion involve any aspiration to fullness. Even inclusion as an exit option (i.e. the option of withdrawing from systemic participation) in politics, the arts and the media shows that inclusion can paradoxically occur as self-exclusion, i.e. when someone -having the opportunity to do otherwise-declines to vote, buy or sell, or be a spectator of an art or the public of the media. Indirect inclusion, meanwhile implies exclusion from the system itself only to be included in it through another — as in the inclusion of the sub-included in functional outputs through informal networks - In the case of inclusion of publics, inclusion though cooption certainly involves exclusion from other options. And inclusion in secondary roles supposes exclusions from central operations of the system. These are forms of exclusion within systems, in other words inclusion in exclusion. People are thus neither included nor excluded, nor are they in an intermediate position; rather, in the concrete situation in which they operate, they are both included and excluded at the same time.

More recently, Stichweh (Stichweh and Windolf, 2009 , pp. 38-40) reformulated this problem, addressing paradoxical situations of inclusion/exclusion using the distinction between including exclusion and excluding inclusion. The distinction thus re-enters itself and makes paradoxes easier to visualize: youth welfare institutions are an including exclusion insofar as they limit degrees of freedom with a view to "social resettlement" thereafter, while youth gangs function as excluding inclusion because the group is constructed through opposition to the expectations structure of the wider society. The same difference could be applied to organized protest groups (indigenous persons, environmentalists, students) that generate powerful communications of social exclusion to draw attention to their demands for inclusion (including exclusion), and terrorist groups that attract members by reinforcing the irrevocability and irreversibility of their operations of exclusion (excluding inclusion).

Systemic sociology thus takes a decisive step towards "visibilizing" the paradoxes in situations of inclusion/ exclusion, and refines their conceptualization. However, the observation could be still more comprehensive. 


\section{IV}

\section{Inclusion and exclusion in the French school: Pierre Rosanvallon, Jean Paul Fitoussi}

The inclusion/exclusion distinction has been widely applied in France. The popularity of the terms is apparent in the symbiosis between its uses in public discourse and in theory. In the first, the key figure is René Lenoir (1974), for whom the excluded consisted of those with any type of disability or mental illness, drug addicts, and even the elderly and single-parent families. Viewed thus, Lenoir's proposal led to problems typical of binary application of the inclusion/exclusion distinction: dualization of society into the included and the excluded, transformation of processes into states, attribution of (discriminatory) categorizations to individuals, and concealment of the paradoxes of real-life constellations. The distinction helped to show the existence of a problem, but the schematic application prevented adequate description.

When Fitoussi and Rosanvallon (2010, p. 27) stated that "social dynamics cannot be reduced to those who are 'in' and those who are "out"" and added that "exclusion is the result of a process, not a given social state," they were distancing themselves from a binary application of the distinction, making it necessary to determine to which social situations the distinction inclusion/exclusion now refers. The key to understanding this lies not in erasure of the classic modalities of stratification and prioritization (as Luhmann emphasized), but in strong individuation of their forms, which impedes reconstruction of a collective experience of social change. Whereas status used to allow recognition of inclusion in a group, class or community, today these references have become unstable, so the description of collective identities must be complemented by "individual trajectories and their variations over time" (Fitoussi and Rosanvallon, 2010, p. 31).

For Fitoussi and Rosanvallon, this affected the way in which individuals experience their relationships with others: (i) one who was previously an "equal" (same profession, same line of work, same area of residence), is now different: "An executive who has been unemployed for some time, for example, does not experience his situation solely in terms of reduced income: first of all he feels excluded from the world of executives" (Fitoussi and Rosanvallon, 2010, p. 74), and (ii) one who was previously different, is now an "unequal equal": "Over time, the Income differences between a small businessman who goes bankrupt, an unemployed executive and a wage earner with an unsteady job are likely to disappear, but they will still not form a homogenous category" (Fitoussi and Rosanvallon, 2010, p. 76). These authors call this new inequalities or dynamic inequalities (originating in technical, legal or economic developments) which are intertwined with the persistence of structural inequalities (of income, assets and education).

These authors' theoretical strategy is to approach inclusion/exclusion in terms of equality/inequality, and so in the observation of specific situations equalities and inequalities can appear in both inclusion and exclusion. A first result of this strategy is to multiply the descriptive possibilities and visibilize real paradoxes: the included may be unequally included. This makes it possible to observe different degrees of exclusion in inclusion, as occurs in an education system whose quality is highly dependent on families' monetary capacities (Repetto, 2011). Or, equally, the excluded may be the object of egalitarian inclusion through institutionally accepted inequalities that exclude others, as in the case of quotas for women's political participation (Ríos, 2008).

A further result of this strategy is that the equality/ inequality distinction introduces a normative standard into the inclusions/exclusions analysis: equality is favoured over inequality as a universal principle. This demands legitimization when inequality is inherent to the situation: inequality of professions (different professions), for example, is legitimate, but gender inequality (discrimination) is not, and since it is not, justified inequalities must be introduced in order to equalize (quotas in politics, flexibilities in employment, protection in the family). When this does not occur, inclusion in a particular category becomes exclusionary, because it differentiates (ranks) people who were previously equals without justification, treats equals as unequals, results in wage differences between men and women for the same work, and gives rise to different treatment by public services for people with different ethnic identities: "The action of dynamic inequalities generates differences in the immediate environment, and 
consequently, social non-belonging. What is occurring here is a rupture of perceived equality that is even more intolerable because it appears to be baseless" (Fitoussi and Rosanvallon, 2010, p. 103).

Underlying this perspective is the paradigm of solidarity present in French sociology since Durkheim. In this context, exclusion is a weakening of the bonds that keep society together, and inclusion denotes intentional efforts (especially by the State) to maintain that unity. According to Rosanvallon (2000), the combination of this perspective with the new inequalities is the new social question: "Two major problems appear in the wake of the crisis: the disintegration of the traditional principles of social solidarity, and the inadequacy of 'social rights' as a framework in which to resolve problems of social exclusion and fully legitimate assistance programmes" (Rosanvallon, 2000, p. 4).

The problem is this case is a passive welfare State resulting from the decoupling of welfare and labour. In the mid-twentieth century economy, workers could have a position in the labour structure in small niches of productivity. Their disadvantaged position was compensated for by the State. When the labour situation changed, with the market opening and competition of the late twentieth century, workers lost their employment niches and were left reliant on State assistance: "They have become paid unemployed," and welfare policies became "a system of subsidized exclusion" (Rosanvallon, 2000, pp. 61-63). This is what could be termed compensatory inclusion, which legitimizes different forms of exclusion.

To capture the novelty of this situation, the old paradigm of exclusion as a stable category must be abandoned, to address the "turning points, setbacks and failures that [individuals] have experienced, the divergences and differences that set them apart" (Rosanvallon, 2000, p. 98). The discussion must therefore address processes of exclusion, rather than states. Here, it becomes very important to understand exclusion in a context of global risk and act accordingly (Fitoussi and Stiglitz, 2009).

As may be appreciated, the French school strives to reveal the paradoxes in specific contemporary situations of inclusion/exclusion and to supply a dynamic conceptual framework for observing them.

Below, this framework is systematized through conceptual distinction of various constellations of inclusion/exclusion, bringing paradoxes into the light and helping to analyse them in more detail.

\section{V}

\section{Constellations of inclusion and exclusion in modern society}

Whatever the forms and combinations of inclusion and exclusion considered, the theories examined suggest that two considerations are always relevant: (i) the first refers to the individuation of processes of inclusion/exclusion and explores people's ability to chose among the options they consider best in relation to their view of their life; (ii) the second has to do with the general social contexts in which processes of inclusion/exclusion take place, and the main issue is the extent to which different levels of social organization are capable of offering alternatives that are adequate in number and diversity, such that institutions can cover the range of options (in depth and breadth). Figure 1 offers a representation of these two macrovariables and the different constellations of inclusion/exclusion proposed. 
FIGURE 1

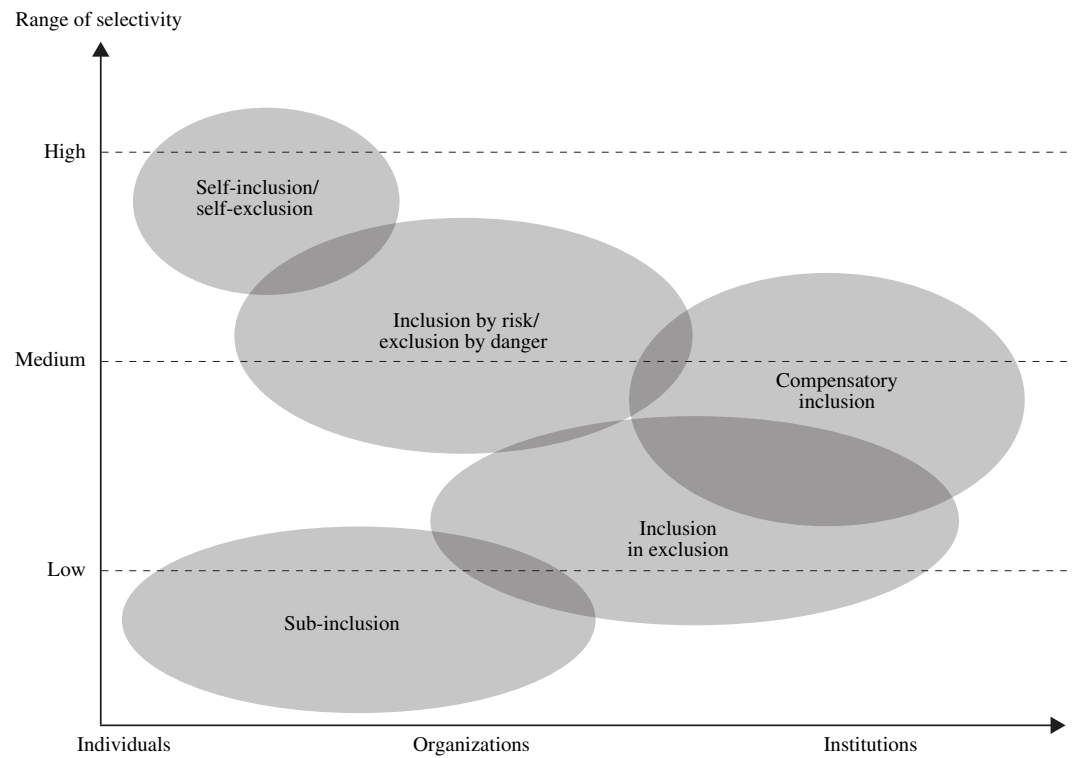

Source: Prepared by the authors.

- Self-inclusion/self-exclusion. A situation little considered in inclusion/exclusion theories is one in which individuals autonomously chose to participate or not in a particular social output. The clearest example of this is participation in religion. Those who consider themselves non-believers $-36 \%$ worldwide, including the non-religious and atheists (wIN-Gallup International, 2012) — allow themselves self-exclusion from religious practice which, nevertheless, remains available for future inclusions. Viewed from the standpoint of religion, self-exclusion does not prevent (i) this individual being considered as included (as a brother, neighbour, child of God, or as an infidel, i.e. a form of inclusion through cooption in which the included party does not consent to the inclusion), or, furthermore, (ii) the operations of the system being geared towards his effective inclusion (through evangelization, compassion or the death of infidels - although the latter would be an extreme form of excluding inclusion, as in the case of the grouping known as Islamic State). Accordingly, the possibility of reverting self-exclusion through self-inclusion is always available: people can believe again or believe for the first time.

For situations of self-inclusion/self-exclusion to be possible, people must have the individual capacities to identify and obtain the means to their ends (in classic terms: education and average income), and this must converge with different social contexts that must provide an environment of diversity and choice, so that if one option is not available, another equivalent will be, without implying substantial changes in individual's life plans. In such a convergence of individual and social conditions, if someone leaves a job (self-exclusion) or even loses it, that person has access to a range of other possibilities in the form of eligible equivalent jobs (self-inclusion). Similarly, if a chosen place of study (self-inclusion) does not meet expectations, not only does the individual have the means (monetary and cognitive) to chose another, but society also provides the equivalent spaces.

In situations of lack of employment such as those described by Rosanvallon ("paid unemployed," "subsidized exclusion"), and amid persistent structural inequalities, this possibility of selfexclusion /self-inclusion is limited to the upper strata of society. Only at this level can individuals expect to be communicationally relevant for social systems and to see this expectation realized by means of bank provision of saving and loan services, private health insurance, university scholarships or even a new and better job. This presupposes a 
high capacity for personal selection and decision and institutions capable of offering a range of alternatives. Self-inclusion/self-exclusion links people with the material and cognitive means to move within a varied institutional environment. Be this as it may, it does not mean a permanent state of inclusion. Ranges of individual selectivity can be rapidly and drastically reduced when a senior executive loses his job and the context of social crisis offers no alternatives at the same level. This triggers the high integration of exclusion described by Luhmann (2005). In a monetized social context, for example, long-lasting unemployment can mean mortgage foreclosure, moving children to a different school, changing health insurance and the destructuring of the identity references of those affected, which reintroduces the problem of new inequalities signalled by Fitoussi and Rosanvallon (2010).

- Inclusion by risk and exclusion by danger. Whereas self-inclusion/self-exclusion emphasizes the mobility of individual options in relation to social contingency, in the case of inclusion by risk/exclusion by danger the emphasis is on organizational decisions. The need to take a decision leads to a situation of growing complexity in which one of the alternatives must be chosen. But the unintended effects of organizational decisions are always amplified to levels that are hard to determine: extending high-risk (subprime) mortgages to local clients can unleash a global financial crisis; innovations in technological systems can be used to invade privacy; savings decisions in industrial facilities can cause environmental catastrophes; deficient fiscal policies can trigger long-term unemployment, drastically limit people's plans or force mass migrations.

These events can leave a large number of people in highly ambiguous situations: they are excluded from organizational making of certain decisions that may affect them, but they are included in these decisions insofar as they may be affected by their consequences. This problem increases with the transnationalization of organizations, because the makers of decisions that may have local effects can be outside the jurisdiction of the authorities in the territory where their decisions cause dangers. ${ }^{2}$ At

2 This is exemplified by investment disputes between private corporations and States, or the prosecution of cybercrime (Mereminskaya, 2014; Shull, 2014). the same time, technical decisions (whether to raise or lower interest rates, implement technological innovations, save on safety matters) have extensive normative consequences in terms of unsought changes in people's life plans, or in terms of the associated political costs. Organizations can take the risk of making a decision, because it is assumed that it is the best decision from a strategic, technical or even political point of view, given the information available. They can even prepare for possible failures by means of policies to mitigate consequences (compensatory inclusion in the form of corporate social responsibility). But the person outside the decision-making process who is not consulted or in some way considered in a decision that will inevitably affect him, is beyond all possibility of avoidance or safeguarding from the consequences of the decision. This is no longer risk, because there is no selectivity option vis-à-vis the consequences; here the individual is subject to the potential danger of a risky decision taken by another (Luhmann, 2006).

In these terms, since risk is selection of one option among several by making a decision, social organizations and institutions design their policies from the point of view of inclusion in the risk of deciding. They may have mechanisms for consultation with those potentially affected (such as community plebiscites or user surveys) or procedures for including them in the actual decision-making (roundtables, participatory budgeting, community councils) (Mascareño, 2010). These mechanisms never reach all those potentially affected, however (Karlsson, 2012). There is always a group excluded from the decision, in other words, included in the danger of others' decisions. This is a serious democratic problem, because exclusion by danger limits concretization of people's right to consent on matters that may affect them, and this increases the new inequalities (Fitoussi and Rosanvallon, 2010). Affected persons are included in the consequences, but excluded from the decisions, for example, in the event of a unilateral change in the contractual conditions of commercial matters (in banking, retail and major department stores) (Ossandón, 2012), in the radical change of a public transport system, as occurred with the Transantiago system in Chile (Briones, 2009), or in the use of indigenous territories for forestry or industry without prior consultation as set forth in the provisions of the Indigenous and Tribal Peoples Convention, 1989 
(No. 169) of the International Labour Organization (ILO) (Mereminskaya, 2011).

Those affected participate under a form of inclusion as cooption. In the sense of Stichweh (2005), they are included as a public, but without the voice/ exit-options that would enable them to deliberate on issues that could affect them, or withdraw from the impacts that may occur. They are left in a kind of excluding inclusion: tied to the outcomes of a process which they have not explicitly sought or accepted.

- Compensatory inclusion. Compensatory inclusion is probably the most traditional form of inclusion and the most associated with the re-establishment of equality vis-à-vis unjustifiable (therefore illegitimate) contingent differences. Broadly defined, compensatory inclusion is carried out by social institutions (usually, but not always, public institutions), through public policies, subsidies, legislation or ad hoc actions, to balance situations which are assumed to be temporary: illness, short-term unemployment, welfare assistance in old age, poverty or catastrophe (Fitoussi and Rosanvallon, 2010). Compensatory inclusion is both an including exclusion, insofar as it identifies a disadvantaged group, unequal to others, regarding whom an intervention is geared towards (re)inclusion. Since compensatory inclusion (especially by the State) assumes that the exclusions targeted are temporary situations, when these situations become permanent they tend to lead to demands for the compensation to be permanent, as well. This was the problem faced by welfare States in the second half of the twentieth century. The monetary cost of these State outputs was known as the crisis of the welfare State in the 1980s (Luhmann, 2007b; Offe, 2007), in which unemployment played a central role. Structural unemployment, as it was known (Standing, 1983; Rodríguez, 1993), produced structural exclusion which required structural compensation. But given that the costs of compensation grow increasingly high for the State, the quality of compensation becomes unsatisfactory for individuals. As unemployment becomes long-term, a chain of exclusions arise in other spheres (place of residence, education, health care), which then become further compensatory demands upon the State. Compensatory inclusion thus becomes an excluding inclusion, inasmuch as it includes those affected, but does so in inequality, i.e. it legitimizes and institutionalizes inequalities. For example, as in the case of Chile, people on low and medium incomes have certain progressively restricted educational options compared with their higher-income compatriots (Torche, 2005). The State may offer compensatory policies such as subsidies or tax discounts for education (SII, 2013), but these are still not enough to balance out the selectivity ranges for interested parties and they stratify access to educational outputs of diverse quality. In other words, there is exclusion through progressive reduction of the range of individual (family) options, as well as a stratified inclusion in educational options of decreasing quality, or at least variable, quality. When this becomes routine and associated with semantics of discrimination, we are talking about inclusion in exclusion: there is inclusion, but it is stratified and stigmatized, that is, with structural and semantic exclusion at different levels. ${ }^{3}$

For reasons such as this, Rosanvallon (2000) prefers to change the welfare approach from the idea of compensation on the basis of social rights to the idea of risk. Because everyone faces different risks, the political justification for compensation becomes less relevant: "[The notion of risk] replaces the classical idea of justice, understood as conformity to nature or to an ethical or political norm, with the idea of a purely contractual justice (the system of compensation)" (Rosanvallon, 2000, p. 15). That is, compensation replaces political responsibility for a contractual compact. What Rosanvallon overlooks is that the State's compensation operations also depend on decisions made excluding potential beneficiaries/affected parties and, thus, without consideration for possible future harm to them: compensatory inclusion puts them in danger of exclusion. Lengthy waiting periods for care for potentially serious illnesses are an example (Oliver and Mossialos, 2004); another is support for trade unions that lobby for universal access to work but exclude women who need flexible working conditions in order to enter stable employment (Abramo, 2006).

In these terms, compensatory inclusion functions with paradoxes that can be controlled when the exclusions it addresses are limited in time; by contrast, when the exclusions become permanent, the paradoxes multiply and it can no longer be certain that the State interventions are producing

\footnotetext{
3 We return to this in "inclusion in exclusion".
} 
generalized welfare. A series of non-governmental institutions, national and transnational, address (and, in some cases, profit from) this problem, aiming to limit the chain of exclusions that can arise as a result of the systematic stratification of access caused by compensatory inclusion (community and church organizations, private welfare foundations, international development organizations). But, like the State, they too are subject to the paradoxes of compensatory inclusion.

A greater problem arises, however, when compensations (public or private, national or international) fail or become routine. In these cases, instances of inclusion in exclusion and sub-inclusion become entrenched. This is discussed next.

- Inclusion in exclusion. Inclusion in exclusion implies inclusion, but in a position of subordination compared with other social categories. Inclusion in exclusion supposes asymmetry between groups, generally justified in traditional or community terms. Group semantics and discourses play a preponderant role in this. Post-colonial theories refer to subalterns (Guha and Spivak, 1988): groups who suffer discrimination on the basis of ethnic origin, caste, class, gender, sexual orientation, language or religion. Without adopting that denomination or the political elements that go with it, it is nevertheless true that inclusion in exclusion is sustained by public discourses that: (i) form social categories on the basis of certain features that are understood to be shared by them, but do not necessarily form part of their self-description; (ii) public stabilization of that discourse leads the group to incorporate/adopt these externally formed categories, and (iii) the adoption of these categories situates the group in a position of subordination relative to the dominant discourse, which is reproduced by the same group to the extent that it assumes its hetero-categorization. Probably the clearest example of this is gender categories. For Butler (2007, p. 49), the very category of woman is insufficient to capture "what one is [...] because gender is not always constituted coherently or consistently across different historical contexts and it is interwoven with race, class, ethnic, sexual and regional modalities or discursively constituted identities." From this it derives that even when the semantics of woman are used with emancipatory intent (activism), subordination flows from within the demand: every claim for woman is an actualization of that subordination. The struggle for inclusion excludes (Mascareño, 2013). But the problem is not only expressed in terms of identification processes. It also has structural consequences in employment segregation by gender, in the concentration of women in the lower rungs of the occupational hierarchy, and in the wage gaps that result from these classifications (Mora, 2013; Uribe, 2008). Something similar occurs with migrants. Especially for lower-skilled migrant workers, the conditions of inclusion not only consist of precarious forms of employment (low-wage, sporadic, without a contract), but also involve ethnic discrimination, particularly, in Latin America, in the case of workers from Andean countries (Mora, 2009). Here, there is inclusion, although it has progressive and systematic restrictions on ranges of selectivity, which lead to different degrees of inclusion in exclusion.

A subtle, but equally illustrative, example of inclusion in exclusion is that of processes of cultural identification. ${ }^{4}$ In his critique of the essentialist concept of culture underlying positions of liberal multiculturalism, Sergio Costa (2012) argues that, by following this approach, the modern State legitimizes the protection of minorities by means of safeguards and limits within which identities can be reproduced without the risk of external intervention diluting them through assimilation. Liberal multiculturalism is thus based on paradoxical suppositions: that cultural identity does not change (because it has an immutable essential substrate), but it is assumed it needs to be protected from changing (protection against assimilation). On this dual basis, the guarantees enshrined in the Constitution of Brazil of 1988, which was created in a highly progressive political environment, included recognition of rural property for descendents of former slave communities (quilombos). Until 1988 there were no groups demanding such recognition, but the article in the Constitution encouraged political mobilizations that saw this as an opportunity to resolve land issues. These mobilizations also involved a series of "external" agents: anthropologists, members of religious orders, activists, agents of the State and the media.

\footnotetext{
4 The heavily criticized culture of poverty approach (Lewis, 1975) could also be considered inclusion in exclusion. In its original form, however, it was understood as an endogenous group production that was self-sustaining across generations. This limits its understanding as a relational problem to which certain features are attributed and then adopted as self-description by other groups, and which, moreover, conceals structural variables (especially relations of subordination) that determine the production of those identification processes (Harris, 2001).
} 
In 2003, a presidential decree established that the procedure for declaring slave ascendancy would be based on self-identification. By late 2011, there were 3.524 communities descended from quilombos. One of them was the Mocambo community, which had always expressed a non-indigenous rural identity: "The legal advantages [...] were persuasive, leading the Mocambo residents, after many discussions and political disputes, to publically accept themselves as a remnant quilombo community" (Costa, 2012, p. 150).

This example illustrates how the State set out originally to pursue inclusion (access to land), but for this it had to define a cultural identity that would be benefited by the inclusion. The symbolic relevance of that identity (associated with solving land issues) led to the exclusion of other possibilities, so that the group was subordinated to the form of identification constructed by the State.

Inclusion in exclusion reveals multiple paradoxes. It expands when we understand that it can combine with exclusion by danger (exclusion of discriminated groups from decision-making) or with compensated inclusion (limitations on inclusion on the basis of discriminatory discourse). Or when it heralds entry into sub-inclusion, as discussed below.

- Sub-inclusion. Sub-inclusion implies the lack of institutional conditions to fulfil fundamental rights, but the obligation to respond to a social order that exacts obedience (Neves, 2006). In other words, it is a denial of the rights that underlie any possibility of positive social inclusion (participation in institutional or organizational outputs), but a reaffirmation of obligations they include, and even the threat of physical force in response to deviation from the norm. There is much insistence on these obligations for such groups, because, unable to find an institutional way out of sub-inclusion, they may resort to violence, crime, illegality or subversion of the general order. However, often the main concern of the sub-included is sheer survival: refugees, migrants in war zones, victims of political persecution, the homeless, and the extremely poor. Certain groups suffer a convergence of discriminations that not only limit universal accessibility to institutional outputs, but also lead to the formation of areas in which the rule of law has no effective or symbolic application (slums, favelas) (Mascareño, 2012b and 2014), or groups that are systematically denied access to certain spaces or positions that are in principle universal (indigenous persons, gays, migrants).
In this sense, sub-inclusion is characterized by the denial of individual autonomy and the utmost restriction of degrees of selectivity.

For all those in a state of sub-inclusion, any aspiration to fulfil life plans through compensatory institutions is suspended. Historically, in Latin American sociology this has been termed marginality, hard poverty and extreme poverty (Nun, 2001; Kessler and Di Virgilio, 2008); governments have attempted to resolve it through compensatory policies which, so long as the poverty persists, must be considered to have failed. Given this failure, people seek alternatives in the informal sector to achieve some level of (sub)inclusion, for example, in community networks, occasional jobs or the informal market. The alternative of engaging with illegal rings (of crime, drug trafficking, corruption) may seem attractive, inasmuch as it promises access to otherwise inaccessible objects and resources (Dewey, 2012). What this produces is a sort of inclusion achieved through generally illegitimate means, which are thus not subject to bureaucratic restrictions, nor do they have any sort of social or legal protection. Those involved gain access to certain outputs they need for survival or to fulfil a modus vivendi through informal means, but at the cost of entering a milieu unprotected by the law or the formal institutions, and needless to say, at the risk of legal prosecution for any punishable action.

Undoubtedly sub-inclusion is not the only condition that motivates participation in informal networks or illegal rings. Indeed, those in a state of subinclusion lack the resources or contacts to organize such rings; they have to be formed already for subincluded individuals to be co-opted or to include themselves. But even those with the broadest ranges of selectivity (self-inclusion/self-exclusion) can diverge into illegal networks or rings (for purposes of tax evasion, market collusion, environmental bribes). The sphere of the State responsible for compensated inclusion is also vulnerable to this problem (corruption, political patronage, favours trading, unregulated lobbying). The difference is that the sub-included: (i) have illegality as the only alternative; (ii) are blamed as "responsible" when such rings are uncovered, and (iii) enable the upper echelons of the ring to continue operating and to regroup in due course. In that sense sub-inclusion, moreover, aids the particularistic (informal, but above all illegal) privileges of others, helping to reproduce and conceal them. 


\section{VI}

\section{Conclusion}

The difference between inclusion and exclusion is undeniably useful for sociological analysis and for public policies in complex societies. However, precisely that high degree of complexity prevents a simplistic analysis that attributes a state of inclusion to some and exclusion to others. The aim of this article has been to elaborate an analytical model of different situations in which inclusion and exclusion are intertwined, supported by illustrations and examples. A number of conclusions may be drawn from this exercise. Below are set forth conceptual conclusions, first, then conclusions with a bearing on policy design and implementation.

In conceptual terms, relations between inclusion and exclusion link individual expectations with organizational or institutional outputs with high, medium or low levels of selectivity. The broadest range of selectivity occurs when people may decide whether (and when) to participate in different social spheres. For example, high-income individuals can choose higher-cost private education or health care, or opt to save and use State alternatives. The level of selectivity decreases progressively for other situations of inclusion/exclusion. Without procedures for consultation with potential affected parties (exclusion by danger), organizational or institutional decisions affect people who have to deal with the consequences using their own resources, or wait for forms of compensatory inclusion (generally from public agencies), in which the range of selectivity available is institutionally predefined. Inclusion in exclusion discriminates culturally and leaves people subordinated to organizational or institutional contexts. Sub-inclusion, meanwhile, is associated with the narrowest range of individual selectivity. This both prevents the fulfilment of the fundamental rights of each individual and implies their submission to legally imposed obligations.

There may be permanent mobility between the different forms of inclusion and exclusion, especially on the boundaries between self-inclusion/self-exclusion and compensatory inclusion, or between inclusion in exclusion and sub-inclusion. Individuals move in a transitional space which can rarely be identified with permanent states. This may explain what Araujo and Martuccelli (2011, p. 168) term positional inconsistency in the social stratification: "The sense that anything can change at any time." Even for the sub-included (those with the most limited selectivity), formal institutional channels can offer a way out towards compensatory inclusion, where, nevertheless, they face the consequences of discriminatory discourses of inclusion in exclusion. At the same time, the broad capacity to decide conferred by self-inclusion/self-exclusion can be reduced by situational contingencies (financial crises, illness, accidents), by individual decisions (to save by switching to the public education or health system), or by third-party decisions (expropriations, a crisis in the firm where an individual is employed), which can lead people towards areas of compensatory inclusion in order to satisfy particular expectations. Complexity permanently deconstructs stratification, but does not eliminate it. Accordingly, differences in selectivity and inclusion may be identified, but not fixed in position. In other words, the distinction inclusion/exclusion cannot be applied in a binary fashion under highly complex social conditions.

This must be a key consideration for designing and implementing public policies: it is not possible to continue talking about inclusion and exclusion as if they were two separate worlds, as if only the sub-included were excluded, or only those with the capacity for selfinclusion and self-exclusion were included. Neither can exclusion be identified with extreme poverty and inclusion with crossing the poverty line: the first is a case of sub-inclusion, while the second is at least compensated inclusion. The binary formula of inclusion/exclusion is too rigid for this type of problem. Both mobility in borderline areas and the multiple social dimensions in which participation and non-participation occur in parallel, make this formula too simplistic, trivializing the objects of policies, distorting their effects and preventing a proper analysis of the problems in hand.

Finally, any measure, whether public or private, must be taken with awareness of its potential exclusionary outcomes. This is especially important when designing and implementing programmes based on technical models that do not consider those who will be affected in the future, and when programmes themselves reinforce the stratification of inclusion in exclusion. There can be no decision without consequences, especially when it comes to public organizations and institutions: it is not possible to precisely calculate the number of possible affected.

While it is true that synergy and complementarity between social programmes and broader public policies 
are essential to bar possibilities of exclusion, it is also true that, whatever the policy framework, there will always be exclusion issues that will have to be treated with flexibility. For this it is necessary, first, to have sufficiently fine-tuned concepts to apply to case analysis and to assessment of the outcomes of each decision, whether public or private. A broad distinction between inclusion and exclusion is confusing and oversimplifies problems that are by nature complex. The model presented here, on the basis of five interrelated situations of inclusion/ exclusion, attempts to expand the sociological and policy capacity to observe and process this complexity.

\section{Bibliography}

Abramo, L. (ed.) (2006), Trabajo decente y equidad de género en América Latina, Santiago, International Labour Office.

Allman, D. (2012), "The Sociology of Social Inclusion", sAgE Open [online] http://sgo.sagepub.com/content/3/1/2158244012471957.

Araujo, K. and D. Martuccelli (2011), "Positional inconsistency: a new concept in social stratification", CEPAL Review, No. 103 (LC/G.2487-P), Santiago.

Braeckman, A. (2006), "Niklas Luhmann's systems theoretical redescription of the inclusion/exclusion debate", Philosophy \& Social Criticism, vol. 32, No. 1, SAGE.

Briones, I. (2009), "Transantiago: un problema de información", Estudios Públicos, No. 116, Santiago, Centre for Public Studies.

Butler, J. (2007), El género en disputa, Barcelona, Paidós.

Costa, S. (2012), "Freezing differences. Politics, law, and the invention of cultural diversity in Latin America", Legitimization in World Society, A. Mascareño and K. Araujo (eds.), Surrey, Ashgate.

Davies, J. (2005), "The social exclusion debate: strategies, controversies and dilemmas", Policy Studies, vol. 26, No. 1, London, Routledge.

Dewey, M. (2012), "Illegal police protection and the market for stolen vehicles in Buenos Aires", Journal of Latin American Studies, vol. 44, No. 4, Cambridge University Press.

Durkheim, É. (2002), Suicide, London, Routledge. (2001), La división del trabajo social, Madrid, Akal.

Fitoussi, J.P. and P. Rosanvallon (2010), La nueva era de las desigualdades, Buenos Aires, Manantial.

Fitoussi, J.P. and J. Stiglitz (2009), "The ways out of the crisis and the building of a more cohesive world", Document de Travail, No. 17, Centre de Recherche en Économie de Sciences Po.

Goodin, R. (1996), "Inclusion and exclusion", European Journal of Sociology, vol. 37, No. 2, Cambridge, Cambridge University Press.

Guha, R. and G. Spivak (eds.) (1988), Selected Subaltern Studies, Oxford, Oxford University Press.

Harris, M. (2001), Antropología cultural, Madrid, Alianza.

Karlsson, J. (2012), "The boundaries of transnational democracy: alternatives to the all-affected principle", Review of International Studies, vol. 38, No. 2, Cambridge, Cambridge University Press.

Kessler, G. and M.M. Di Virgilio (2008), "The new urban poverty: global, regional and Argentine dynamics during the last two decades", CEPAL Review, No. 95 (LC/G.2382-P), Santiago.

Lenoir, R. (1974), Les exclus: un français sur dix, Paris, Seuil.

Lewis, O. (1975), Five Families: Mexican Case Studies in the Culture of Poverty, London, Basic Books.

Luhmann, N. (2007a), La sociedad de la sociedad, Mexico City, Herder. (2007b), Teoría política en el Estado de bienestar, Madrid, Alianza Editorial.

(2006), Sociología del riesgo, Mexico City, Ibero-American University.

(2005), "Inklusion und Exklusion", Soziologische Aufklärung, No. 6, Wiesbaden, vs Verlag.

(1993), Gesellschaftsstruktur und Semantik, Band 3, Frankfurt, Suhrkamp.

MacPherson, S. (1997), "Social exclusion”, Journal of Social Policy, vol. 26, No. 4, Cambridge, Cambridge University Press.
Mascareño, A. (2014), "Grenzen der Kontrolle: Institutionalisierung und Informalisierung des Raums. Das Beispiel Lateinamerika", Konstruktion und Kontrolle. Zur Raumordnung sozialer Systeme, P. Goeke, R. Lippuner and J. Wirths (eds.), Wiesbaden, Springer vs.

(2013), "Los varios rostros del género y sus fundamentos estructurales", Desigualdad en Chile: la continua relevancia del género, C. Mora (ed.), Santiago, Ediciones Universidad Alberto Hurtado.

(2012a), "The many faces of justice and its structural foundations", Legitimization in World Society, A. Mascareño and K. Araujo (eds.), Surrey, Ashgate.

(2012b), Die Moderne Lateinamerikas. Weltgesellschaft, Region und funktionale Differenzierung, Bielefeld.

(2010), "Social coordination through public policies: the Chilean case", CEPAL Review, No. 101 (LC/G.2455-P), Santiago.

Mereminskaya, E. (2014), Arbitraje comercial internacional en Chile. Desafíos y desarrollo, Santiago, Thomson Reuters.

(2011), "El Convenio 169 de la OIT sobre pueblos indígenas y tribales. Derecho internacional y experiencias comparadas", Estudios Públicos, No. 121, Santiago, Centre for Public Studies.

Mora, C. (ed.) (2013), Desigualdad en Chile: la continua relevancia del género, Santiago, Ediciones Universidad Alberto Hurtado.

(2009), "Estratificación social y migración intrarregional: algunas caracterizaciones de la experiencia migratoria en Latinoamérica", Universum, vol. 24, No. 1, Talca, University of Talca.

Neves, M. (2006), "Die Staaten im Zentrum und die Staaten an der Peripherie", Soziale Systeme, vol. 12, No. 2, Stuttgart, Lucius \& Lucius Verlag.

Nun, J. (2001), Marginalidad y exclusión social, Buenos Aires, Fondo de Cultura Económica.

Offe, C. (2007), Contradicciones en el Estado de bienestar, Madrid, Alianza.

Oliver, A. and E. Mossialos (2004), "Equity of access to health care: outlining the foundations for action", Journal of Epidemiology and Community Health, vol. 58, No. 8.

Ossandón, J. (ed.) (2012), Destapando la caja negra. Sociologías de los créditos de consumo en Chile, Santiago, Instituto de Investigación en Ciencias Sociales (ICSO).

Parsons, T. (2007), American Society. A Theory of the Societal Community, Boulder, Paradigm Publishers.

(1965), "Full citizenship for the negro American? A sociological problem”, Daedalus, vol. 94, No. 4, Cambridge, Massachusetts, The MIT Press.

Porter, F. (2000), “Social exclusion: what's in a name?", Development in Practice, vol. 10, No. 1, Taylor \& Francis.

Rawal, N. (2008), "Social inclusion and exclusion: a review", Dhaulagiri Journal of Sociology and Anthropology, vol. 2.

Repetto, A. (2011), "The effectiveness of private voucher education: evidence from structural switches", Educational Evaluation and Policy Analysis, vol. 33, No. 2, June.

Ríos, M. (ed.) (2008), Mujer y política. El impacto de las cuotas de género en América Latina, Santiago, Catalonia. 
Robles, F. (2005), "Contramodernidad y desigualdad social: individualización e individuación, inclusión/exclusión y construcción de identidad. La necesidad de una sociología de la exclusión", Revista Mad, No. 12.

Rodríguez, O. (1993), La teoría del subdesarrollo de la CEPAL, Buenos Aires, Siglo XXI.

Rosanvallon, P. (2000), The New Social Question. Rethinking the Welfare State, Princeton, Princeton University Press.

Sánchez, K. (2012), "Social exclusion, social cohesion: Defining narratives for development in Latin America", Journal of International Development, vol. 24, No. 6, Hoboken, John Wiley \& Sons.

Shull, A. (2014), "Global cybercrime: the interplay of politics and law", Internet Governance Papers, No. 8, Centre for International Governance Innovation.

SII (Internal Revenue Service) (2013), "Rebaja de impuestos por gastos en educación" [online] http://www.sii.cl/pagina/intermedia/ beneficio_educacion/beneficio_educacion.html.

Silver, H. (1994), "Social exclusion and social solidarity: three paradigms", International Labour Review, vol. 133, No. 5/6, Geneva, International Labour Organization (ILO).
Simmel, G. (1992), Soziologie, Frankfurt, Suhrkamp.

(1950a), "The stranger", The Sociology of George Simmel, K. Wolff (ed.), Glencoe, Illinois, The Free Press.

(1950b), "The secret and the secret society", The Sociology of George Simmel, K. Wolff (ed.), Glencoe, Illinois, The Free Press.

Standing, G. (1983), "The notion of structural unemployment", International Labour Review, vol. 122, No. 2, Geneva, International Labour Organization (ILO).

Stichweh, R. (2005), Inklusion und Exklusion. Studien zur Gesellschaftstheorie, Bielefeld, Verlag.

Stichweh, R. and P. Windolf (eds.) (2009), Inklusion und Exklusion: Analysen zur Sozialstruktur und sozialen Ungleichheit, Wiesbaden, vs Verlag.

Torche, F. (2005), "Privatization reform and inequality of educational opportunity: the case of Chile", Sociology of Education, No. 78.

Uribe, V. (2008), "Inequidades de género en el mercado laboral: el rol de la división sexual del trabajo", Cuaderno de Investigación, No. 35, Santiago, Directorate of Labour.

wIN-Gallup International (2012), "Global Index of Religiosity and Atheism" [online] http://www.wingia.com/web/files/news/14/ file/14.pdf. 